\title{
SMART VILLAGES AND INVESTMENTS TO PUBLIC SERVICES AND ICT INFRASTRUCTURE: CASE OF THE CZECH RURAL DEVELOPMENT PROGRAM 2007-2013
}

Martin Pělucha ${ }^{1}$

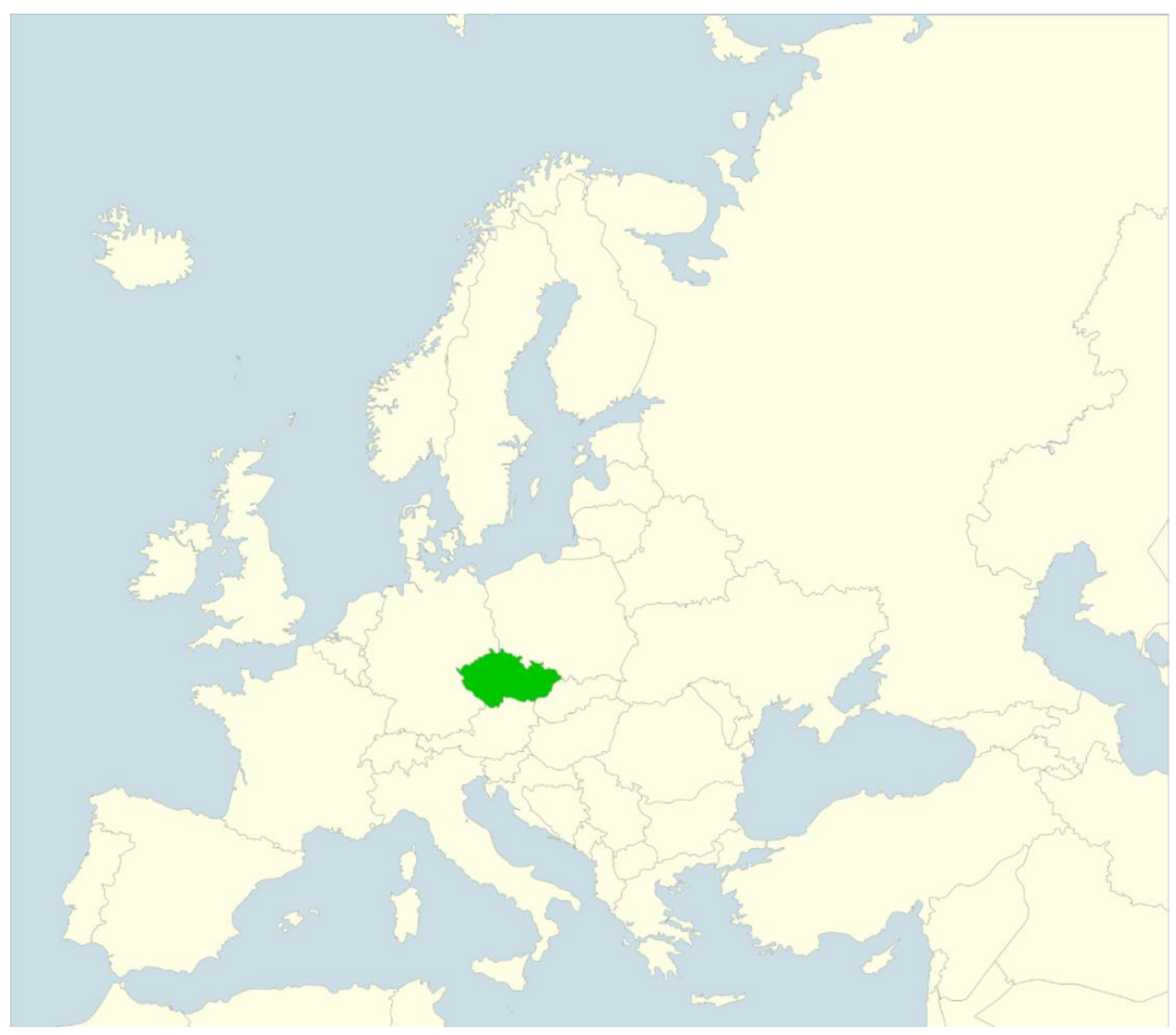

1 Doc. Ing. Martin Pělucha, Ph.D., University of Economics, Prague, Czechia, e-mail: pelucham@vse.cz, ORCID: 0000-0003-2024-5964. 


\begin{abstract}
The basis for SMART VILLAGE development is a high-quality infrastructure for civilian equipment and services, including the coverage of rural villages by highspeed Internet. The aim of the article is to evaluate the support and impacts of these activities through the Czech Rural Development Program in the period 2007-2013 and, according to the ex-post evaluation, to further identify policy-implications. The results of the analysis show a clear positive impact of the support of the service infrastructure on the development of supported municipalities, on the contrary, the results of supporting the connection of the rural population to the Internet are patchy.
\end{abstract}

Key words: public services, rural development, SMART village, ICT infrastructure

\title{
1. Introduction
}

SMART Village is relatively new in academic literature. In general, the issue of smart city in relation to digital development in urban areas is more discussed (Etezadzadeh, 2016). The term "smart" is a synonym for intelligent and digital coherence. Various authors also investigated the parameters of the smart development, which builds on the long-term trends of information society development, which is also sometimes referred to as the Society 4.0. (see, e.g., Combes and Overman 2004; Barca et al. 2012; Haupt, 2018). Considering the agglomeration savings for building the necessary Information and Communication Technologies (ICT), urban areas have an obvious advantage over rural sites lacking the necessary critical mass (Mitchell, 2007; Eger 2009). This problem is a typical trait of rural locations, which in the case of a particular loop creates conditions for the so-called vicious circle of rural areas, especially peripheral and distant from urban centers or key transport communications (OECD, 2006). The problem of geographical disadvantage of some types of rural areas is given, and the possibility of developing shrinking regions not only in the literature but also at the level of policy makers (ESPON, 2017a) is being discussed. These regions are disadvantaged by a complex of interrelated factors. The paradigm shift in understanding is based on tools through which these regions can be helped in their socio-economic and environmental stabilization. Smart development can be one of the possible tools to help these types of rural areas and especially small rural communities. However, according to Salemink et al. (2017), smart development is a very broad and comprehensive concept that is also related to the sharing of best-practice, innovation, and technological development. The availability of highquality services and high-speed internet in the countryside is also a sub-component of this theme, which should increase the attractiveness of these areas during the digitization period (Corey and Wilson, 2006; European Commission, 2017a). Rural studies therefore focus their attention only in the last few years on the potential of digital development factors to transform the conditions and opportunities for development of rural stakeholders (Pant \& Odame, 2017).

Digitization and smart development factors are most reflected in the service sector and its development potential. Of course, this trend is also very strong in the agricultural sector, which is referred to as agriculture 4.0. Even in this sector, there are barriers that limit the development potential of this topic in the countryside. For example, according to the European Commission (2017b), the problem of farmers' ability to invest in modernization is also a problem, as is the age structure of farmers, where old farmers have objective digital skills problems. However, the concept SMART village is more complex and does not only cover the agricultural sector. On the contrary, it is a wider use of the possibilities of the digital economy and relevant types of services, which represent a very heterogeneous group of activities. In this context, certain types of sophisticated services in the territory are becoming more accessible to rural areas because of the ongoing digitization. So, in this paper, the SMART village concept is evaluated primarily in terms of creating conditions for the development of the relevant service infrastructure and its impact on the attractiveness of rural communities. This view also makes it possible to assess some elements of the quality of life in rural areas, as improving the availability of certain types of services increases the attractiveness of rural life. 
In the Central and Eastern European countries, the transformation of economies from centrally managed to market-based economies was gradually completed at the turn of the millennium. The transformation has brought about a change in the territorial configuration of service availability in all these countries, which has been concentrated primarily in urban regions. The result was a closure of services (Woods, 2006; Van Steen and Pellenbarg 2010) and a reduction in the attractiveness of a number of rural areas and associated depopulation trends, which in the first decade of the new millennium interrupted suburbanization in catchment areas of metropolitan and regional urban centres. Except for tourist destinations, however, peripheral countryside has become very complicated for residential activities.

The main motivation of the paper is to reflect and discuss the change in rural areas of the Czech Republic, which has a very varied countryside due to the fragmented settlement structure. As in other EU countries, the modified Rural Development Policy of the European Union (EU) supported these areas in the period 2007-2013. Stronger support for nonagricultural rural activities has become a great opportunity for peripheral and remote rural areas of the EU over the period. Stronger support for non-agricultural activities in axis III of this policy has become a major opportunity for rural areas in the EU during the period. One of the relevant measures was the promotion of infrastructure for civil facilities and services, including ICT infrastructure. The aim of this article is to identify the effects and impacts of support for infrastructure services in rural municipalities in the Czech Republic in 2007-2013, which partly focused on supporting the deployment of high-speed Internet. SMART village is a very broad term that relates to the overall functioning of the rural community in the digital era, and ICT infrastructure is one of its cornerstones. Therefore, the hypothesis of this paper is the assumption that clearly targeted financial support for rural areas in the Czech Republic has helped to create the conditions for the development of SMART villages.

The main method of the research is to evaluate the results of the empirical survey (i.e. questionnaire and telephone survey) for supported and unsupported municipalities in the area of service infrastructure and ICT. Key results of this survey are presented through summarized descriptive statistics of the provided support and the context of socioeconomic indicators. In this context, it is worth mentioning the findings of Elshof et al. (2017, p. 41), who emphasized that "the existing research on the impact of local services on flows of movers is limited", and the ambition of this paper is to contribute to filling this gap in the research sphere. Particular attention is paid to assessing the impact of this support on the relevant beneficiaries (i.e. rural municipalities up to 500 inhabitants) and on the impact on socio-economic development. The assessment also includes a comparative analysis of socio-economic development not only in supported municipalities but also in municipalities without this support.

The article is divided into the following sections. This introduction is followed by a literature review that identifies the key issues of the importance of services in rural areas, with specific attention being paid to digital development. The third section describes the tool of rural development policy, which supported the infrastructure of public services and ICT in the Czech countryside. The fourth section is focused on presenting the results of empirical surveys and relevant analyses. The last section contains concluding remarks and reflections for policymaking.

\section{Theoretical background}

Services are a very heterogeneous group of activities, generally referred to as the tertiary sector. Their main trait was that their outputs were consumed at the time of their production (e.g., retail services, education, healthcare, transport). This element has fundamentally changed with globalization and especially the digitization of territory and society. Although some authors have discussed in the past about the end of the rural society in the context of urban-rural lifestyles mixing (Friedland, 1982, 2010; Hoggart, 1990), wider trends have significantly contributed to reducing the importance of distances in the territory. These are globalization, technological development and higher availability of ICT infrastructure (Pělucha et al., 2012). However, this potential is limited by the quality of this infrastructure. Therefore, a number of rural areas have faced the problems associated with the efficiency of providing services in 
remote rural areas lacking critical mass. In addition, if general macroeconomic problems are added to the lack of public funds to support these activities, for example, in the years 2008 to 2010 - the economic crisis, the limitation of these types of services has even been radical in some rural areas (Scott, 2013). Of course, the municipalities are dependent on the level of activity of local stakeholders, who can find alternative forms to provide some types of services, such as a strong community approach (Bailey and Pill, 2015; Haan et al., 2017). The success of some rural communities and their resilience to external factors is heavily dependent on the context of local conditions (Vaznoniené and Pakaltiené, 2017), which cannot be easily applied in other rural communities.

The attractiveness of rural areas and municipalities is influenced by complex of various factors. According to Elshof et al. (2017), these factors include amenity of scenic beauty, other amenities, jobs and village characteristics. This paper focuses on assessing the second set of factors, i.e., other amenities that are seen as specific services that people prefer for their daily lives (Amcoff, 2012; Barakat, 2015; Dustmann and Okatenko, 2014). Services in rural municipalities are the basis of their attractiveness, which is closely linked to the availability of the relevant infrastructure and therefore their importance is crucial. This characteristic is crosscutting and of great importance across all European regions, as highlighted in the ESPON study (2017b, p. 87) in the sense that "good access implies the service is affordable, good quality, universal access". The availability of services is divided by OECD (2016) into physical accessibility (place where services are provided), economic accessibility (affordability, price of services) and institutional accessibility (legislative environment, values and standards of the society). This paper evaluates the physical accessibility of services, their support under the EU rural development policy in the Czech Republic in 2007-2013, including an ex-post analysis of impacts on selected socio-economic indicators.

If a certain rural locality suffers from inadequate accessibility, such as services of general interest (e.g., education, healthcare system, poor transport services), these regions are referred to as regions and locations of inner peripheries. These localities subsequently accumulate problems that cause a decreasing attractiveness for their socio-economic development. That is why it is extremely important for a number of rural municipalities to maintain some types of services, such as maintaining and subsidizing a primary school (Kourilová, 2018). In other cases, municipalities try to either cooperate more with other municipalities in ensuring the service of the territory or, in the context of urban-rural relations, to strengthen and modernize their local economy by means of more intensive use of ICT infrastructure (OECD, 2014).

The importance of services and ICT infrastructure is closely related to the increasing availability of high-speed Internet in the territory (at least mobile networks and wireless broadband). As a result of this modernization, some types of public services can be better achieved in the area, which is often discussed in topics such as e-government, e-health, e-energy and e-transport, which represent an important factor in the development of the digital age (ESPON, 2017c). In the context of the development of the Internet of Things, the possibilities for using other spheres of the digital economy that operate on the basis of virtual connectivity (ESPON, 2017b) are also expanding. In this respect, e-commerce has developed significantly in recent years, which can fundamentally change the spatial patterns of behaviour of residents and entrepreneurs in remote rural areas. According to Eurostat (2018), e-commerce activities are paradoxically most used in the low-populated regions of Scandinavian countries or some rural areas of the United Kingdom, which is related to investments in the relevant infrastructure. According to Roberts and Townsend (2015), poor or inappropriate ICT infrastructure will significantly weaken the quality of digital life and the development of localities over the coming decades, further reducing their attractiveness and competitiveness. However, it is still necessary to emphasize that a very wide range of factors influences the quality of life in rural areas, while subjective perceptions of rural areas are still very pronounced, where each person can perceive the quality of their lives differently (Halfacree 2006; Woods, 2011). However, digitization is a process that cannot be stopped and gradually it can be expected that many types of services will only be accessible through a virtual Internet environment (Scott, 2013a; Lund \& Manyika, 2016) 
The absence of quality ICT infrastructure in peripheral and remote rural areas will deepen the issue of the rural penalty, as defined by Hite (1997) in relation to typical rural characteristics. This is a low population density causing low critical mass, and thus less opportunities for business, service and employment development. If the market fails to provide this type of infrastructure in the territory, then it is a market gap and a public interest in providing funding can be assumed. The weak digital connectivity in the territory is causing serious digital skills deficits and their utilization rates in rural areas (Malecki, 2003; Salemink et al. 2017). The results of such support reduce the disadvantage in the development of rural services, especially for virtual environments. According to the OECD (2010, p. 28) "some technologies (ICT) have reduced the distance penalties to rural regions, the majority of the rural people exchange goods and services are still subject to distance penalties". Still, it will be necessary to provide a certain level of commuting for off-line services.

So what does the concept of SMART village mean in rural areas? As already mentioned in the introduction of the paper, the term SMART is used in academic literature especially in connection with SMART cities or SMART development. The issue of SMART villages has been given more attention in recent years in rural studies (see, for example, Graham, 2011; Philip et al., 2015; Riddlesden and Singleton, 2014), which is related to the digitization of rural areas. The European Commission (2016, p. 3) explains this notion that "the emerging concept of Smart Villages refers to rural areas and communities that build on their existing strengths and assets as well as developing new opportunities. In Smart Villages and new networks, services are enhanced by digital, telecommunication technologies, innovations and better use of knowledge, for the benefit of inhabitants and businesses. Digital technologies and innovations may support quality of life, higher standard of living, public services for citizens, better use of resources, less impact on environment, and new opportunities for rural value chains in terms of products and improved processes". Similarly, the concept of SMART villages defined by Nieto (2019) who tried to provide a definition basis for their support in the period 2021-2027. Specifically, he states "Smart Villages are communities in rural areas that use innovative solutions to improve their resilience, building on local strengths and opportunities. They rely on a participatory approach to develop and implement their strategy to improve their economic, social and/or environmental conditions, in particular by mobilising solutions offered by digital technologies" (Nieto, 2019). It is therefore a combination of the development of service infrastructure and innovative rural activities combined with the building of ICT infrastructure and digital technologies. These issues are evaluated on the example of relevant experience of the Czech Republic in this paper.

If we focus on the term "smart development", it is more often discussed in academic literature in the second decade of the new millennium, following the activities of the Europe 2020 strategy, which emphasized elements of innovative, sustainable and inclusive growth. However, some authors point out that the concept of smart development cannot be applied in all rural areas (e.g. Combes and Overman, 2004; Barca et al., 2012), precisely in connection with the limited service and ICT infrastructure in rural areas. However, this development in the intermediate rural regions and especially in the suburban rural areas may be less problematic as they can better link to the critical mass needed in urban-rural relationships (Bosworth and Venhorst, 2018; Naldi et al., 2015). Moreover, it is evident in these suburban rural areas that people commute far more to work and services, and use their villages mainly as residents (Copus and de Lima, 2015).

In this sense, the setting of EU rural development policy for the period 2007-2013 can be considered crucial for the development of this theme. In that programming period, this policy defined specific interventions focused only on civic amenities and services in Axis III for rural municipalities. On the other hand, in the programming period 2014-2020, this policy shifted towards supporting rural agriculture, which is partly related to the restoration of productivism, respectively to the renewal of neoproductivism in rural development policy (Pelucha \& Kveton, 2017).

So, in the programming period $2007-2013$, the rural facilities were specifically targeted, i.e., the necessary infrastructure for services and ICT. These were e.g., education, health, social, care services for seniors, business infrastructure, buildings for sports or cultural activities, 
training centres using ICT, generally projects to increase the availability and use of ICT. This type of investment in the territory had a direct link to the quality of life of rural stakeholders. Therefore, positive impacts on the socio-economic development of supported municipalities can be assumed. The problem, however, was the financial scale of the tool, which, although well targeted, was financially negligible. This reopens the question of the Caballero paradox (Caballero et al., 2005), which is a mismatch between the objectives and the scope of rural development policy and the results achieved. According to Caballero, it is usually possible to monitor very weak and limited results of rural development policy in any state, which creates a very serious threat and risk for the implementation of a multidisciplinary approach, which can then be criticized as incorrect. The unequal distribution of funding for the development of 'agricultural' and 'non-agricultural' countryside causes the limited impact of this policy on the comprehensive development of rural areas. For this reason, it is necessary to focus on evaluating the results and impacts of supporting thematically targeted rural development policy tools on non-agricultural activities. In connection with the SMART development concept, supporting the development of basic services and ICT infrastructure is the most important.

\section{Delimitation of the evaluated tool and research methodology}

This section presents the EU Rural Policy tool for 2007-2013 and particularly, the ex-post assessment of achieved results and impacts of the measure III.2.1.2 "Civic amenities and services". This measure funded projects only in municipalities under 500 inhabitants. In particular, the provision and development of the missing civil facilities and services, which cannot be financed through mandatory state expenditures. Furthermore, the measure also supported infrastructure for the deployment of high-speed Internet. The link to improving service availability conditions and thus to new jobs thus gave this measure an important socioeconomic dimension. The objectives of the measure have been to improve basic services and increase the attractiveness of rural areas by developing investments and to improve the quality of life in rural areas.

This measure was one of the smallest in the Czech Rural Development Program 2007-2013 (only $1.44 \%$ of the total allocation), because the emphasis in financial allocations was on agricultural measures (i.e., LFA support, agri-environmental measures, etc.). For this reason, the attention in this paper also focuses on evaluating the degree of importance of the subsidies provided for the relevant infrastructure in comparison with other subsidies received by the supported municipalities.

Applicants submitted their project applications for this measure in four calls $(2007,2008,2009$ and 2011). According to the State Agricultural Intervention Fund (SAIF), a total of 1922 applications were submitted, out of which 270 projects were approved. It is necessary to emphasize that a similar tool supporting the complexity of the issue of civic amenities and services in the country was not available in the Czech Republic, which influenced the resulting excess of applicants' demand. Total allocation for measure 49351 thous. EUR was spent $(100 \%)$. Almost all projects focused on construction investments connected with the reconstruction or construction of sports, multipurpose and children's playgrounds, as well as the reconstruction of municipal buildings, including projects focused on building insulation or replacement of windows (e.g., municipal offices, primary schools, kindergartens).

The following methods were used to obtain background materials and sets of indicators as the basis for the formulation of final conclusions:

- Questionnaire survey in the form of a web questionnaire for indicative mapping of the ex-post evaluation baseline situation (beneficiaries and unsuccessful applicants);

- $\quad$ Additional telephone survey on a sample of about $5 \%$ of beneficiaries;

- Statistical assessment of data from the Ministry of Agriculture and Czech Telecommunication Office and a comparative analysis of selected socio-economic data of the CZSO available at the level of supported and unsupported municipalities (LAU II).

The questionnaire survey included 2 web questionnaires, i.e., beneficiaries and unsuccessful applicants. In the questionnaire survey at the level of beneficiaries of measure III.2.1.2, a total of 
67 questionnaires were filled out of a total of 257 addressed subjects, i.e., a return of $26.0 \%$ (note: some beneficiaries implemented more than one project). The results of empirical research are fully representative. The geographical distribution of respondents corresponded to the geographical distribution of all beneficiaries in this measure. Therefore, the results of the questionnaire survey can be considered sufficiently indicative of the development, status and impact of the implementation of support for this measure. In addition, a total of 13 beneficiaries who did not participate in the questionnaire survey were addressed in the telephone survey and thus the representativeness of the empirical survey was further increased by another $5 \%$. Thus, in total, a representative sample covered $31 \%$ of all beneficiaries.

The evaluation also focused specifically on the verification of the development of the number of households with access to high-speed Internet in municipalities where the relevant RDP subsidies were implemented, and also in municipalities with unsuccessful applications for subsidies. According to OECD (2016, p. 32) "a broadband connection is an important requirement for accessing information and other services that shape people's quality of life and affect their opportunities to prosper". These data were provided by the Czech Telecommunication Office and include a comparison of all supported and unsupported municipalities in the given category of investments focused on ICT infrastructure in the evaluated measure.

\section{Results and discussion}

In this section, attention focuses on evaluating the results and impacts of measure III.2.1.2 within three sub-themes, i.e., (1) Perception of the impact of infrastructure projects on community development, (2) Comparison of Internet connection rates in supported and unsupported municipalities, and (3) Socio-economic performance in supported and unsupported municipalities.

\subsection{Perception of the impact of infrastructure projects on community development}

The perception of the impact of supported infrastructure projects is assessed in two respects. Firstly, it is the impact on supported municipalities and their functioning. This is related to the ability of municipalities to provide funding for more expensive infrastructure investments in the area of amenities and services, which should not block the normal agenda of the municipality. This ability is measured by dead weight intervention. Secondly, this is an indicator of the impact of a new or reconstructed infrastructure directly on residents of supported municipalities. This is further supplemented by the results of the questionnaire and telephone surveys in terms of assessing satisfaction with the new or reconstructed infrastructure in the area of amenities and services by representatives of directly supported municipalities.

Infrastructure projects are very demanding in terms of finance, and therefore, these projects are usually very difficult for rural municipalities to conduct without external assistance. When comparing the probability of project implementation for both supported and unsupported applicants, the similar deadweight level is based, i.e. $18.8 \%$ for beneficiaries and $23.9 \%$ for non-supported applicants. The average deadweight for the whole measure is $21.39 \%$, which means that investments were made for approximately every fifth unsupported application. This level corresponds to the nature of unsupported investments, such as the construction or reconstruction of playgrounds, nursery and primary school buildings, municipal offices. The conducted telephone survey with selected beneficiaries showed that rural municipalities must make these investments in order to ensure the quality of life for the inhabitants of the municipality. If these projects were not implemented, the level of development in the given municipalities would be lower or even stagnate. For this reason, the representatives of rural municipalities are trying to secure the relevant funds and to implement these investments partly from their own financial sources or loans if they are not successful in the grant procedure. 
In measure III.2.1.2, two result indicators were defined, i.e., the number of people using improved services, and an increase in the number of people with Internet access. By means of both indicators, it is possible to evaluate the increase in the quality of life of beneficiaries in terms of direct users of the benefits of realized 270 projects. A target value of 150,000 inhabitants has been set for the indicator of the number of people using improved services. As of 31 December 2015, the value of 259,276 inhabitants (i.e., $172.8 \%$ of the target value) was reached. The main positive factor was the inclusion of residents from smaller rural municipalities belonging to the catchment area of the supported municipalities.

Tab 1. Drop-off effect of the measure III.2.1.2 at beneficiary level over time and comparison with perceived consequences of non-implementation proposed projects by unsuccessful applicants. Source: own calculation according to the results of the survey of beneficiaries (2016)

\begin{tabular}{|c|c|c|c|c|c|c|}
\hline & \multicolumn{3}{|c|}{ Beneficiaries } & \multicolumn{3}{|c|}{ Unsuccessful applicants } \\
\hline & $\begin{array}{l}\text { The meaning } \\
\text { decreases }\end{array}$ & $\begin{array}{l}\text { The meaning } \\
\text { remains the } \\
\text { same }\end{array}$ & $\begin{array}{c}\text { Meaning } \\
\text { increases }\end{array}$ & $\begin{array}{l}\text { The situation } \\
\text { got worse }\end{array}$ & $\begin{array}{c}\text { The } \\
\text { meaning } \\
\text { remains the } \\
\text { same }\end{array}$ & $\begin{array}{l}\text { It has } \\
\text { improved due } \\
\text { to other } \\
\text { circumstances }\end{array}$ \\
\hline $\begin{array}{l}\text { Satisfaction of inhabitants in } \\
\text { the village with the quality of } \\
\text { infrastructure }\end{array}$ & $0 \%(n=0)$ & $37 \%(n=20)$ & $63 \%(n=34)$ & $27 \%(n=44)$ & $50 \%(n=81)$ & $23 \%(n=37)$ \\
\hline $\begin{array}{l}\text { Improving the appearance of } \\
\text { the village }\end{array}$ & $0 \%(n=0)$ & $71 \%(n=41)$ & $29 \%(n=17)$ & $25 \%(n=40)$ & $43 \%(n=67)$ & $32 \%(n=50)$ \\
\hline $\begin{array}{l}\text { Creating conditions for new } \\
\text { job opportunities }\end{array}$ & $3 \%(n=1)$ & $31 \%(n=12)$ & $67 \%(n=26)$ & $32 \%(n=30)$ & $54 \%(n=51)$ & $14 \%(n=13)$ \\
\hline $\begin{array}{l}\text { Higher attractiveness of the } \\
\text { municipality for citizens } \\
\text { (interest in permanent } \\
\text { housing) }\end{array}$ & $0 \%(n=0)$ & $37 \%(n=19)$ & $63 \%(n=33)$ & $28 \%(n=45)$ & $52 \%(n=83)$ & $20 \%(n=32)$ \\
\hline $\begin{array}{l}\text { Higher attractiveness of the } \\
\text { municipality for new business } \\
\text { activities }\end{array}$ & $0 \%(n=0)$ & $84 \%(n=27)$ & $16 \%(n=5)$ & $20 \%(n=25)$ & $67 \%(n=82)$ & $12 \%(n=15)$ \\
\hline $\begin{array}{l}\text { Higher attractiveness of the } \\
\text { village for tourists }\end{array}$ & $0 \%(n=0)$ & $42 \%(n=21)$ & $58 \%(n=29)$ & $34 \%(n=51)$ & $50 \%(n=76)$ & $16 \%(n=24)$ \\
\hline
\end{tabular}

The evaluation of the drop-off effect, i.e., the potential reduction of the intervention effect over time, is shown in Table 1 at both the beneficiary and unsuccessful applicants' level. According to particular criteria, the beneficiaries appreciate the fact that the unused building or part of the building in the municipality was renewed ( $87 \%$ of respondents). The civic amenities projects thus significantly contributed to making the supported municipalities more attractive and improving the conditions for ordinary civic activities. On the contrary, the projects did not have any significant impact on the appearance of the municipality or on the improvement of conditions for business activities. In the case of unsuccessful applicants, the situation has been assessed as stagnant in all the monitored factors since their application for support was refused.

\subsection{Comparison of Internet connection rates in supported and unsupported municipalities}

The second monitored indicator was the increase in the number of persons with access to the Internet, whose target value was set at 70,000 inhabitants for the entire 2007-2013 programming period. As of 31 December 2015, the achieved value of 39,591 persons represents approximately $57 \%$ of the target values. In total, 101 projects indicated the number of people with Internet access in their payment requests. The failure to reach the target was mainly due to the fact that promoting the connection of the rural population to the Internet was not the main priority of the beneficiaries. Most of the supported projects linked to this indicator focused on the reconstruction of municipal houses, offices, and cultural houses within which it is possible to connect to the Internet. However, the main purpose of these projects focused on the reconstruction of buildings to provide a wide range of civic services. Internet access was of secondary importance to supported projects. 
Tab 2. Comparison of Number of Supported or Planned Persons to One Internet Connection in Supported and Unsupported Municipalities of the Measure III.2.1.2. Source: own processing and data calculations according to data of the Ministry of Agriculture (2016) and Czech Telecommunication Office (2016)

\begin{tabular}{|r|r|r|r|r|}
\hline & $\begin{array}{c}\text { Number of } \\
\text { supported } / \\
\text { planned residents } \\
\text { from RDP to one } \\
\text { internet access } \\
\mathbf{2 0 1 0}\end{array}$ & $\begin{array}{c}\text { Number of } \\
\text { supported } / \\
\text { planned residents } \\
\text { from RDP to one } \\
\text { internet access } \\
\mathbf{2 0 1 3}\end{array}$ & $\begin{array}{c}\text { Number of } \\
\text { supported } / \\
\text { planned residents } \\
\text { from RDP to one } \\
\text { internet access } \\
\mathbf{2 0 1 4}\end{array}$ & $\begin{array}{c}\text { Number of } \\
\text { supported } / \\
\text { planned residents } \\
\text { from RDP to one } \\
\text { internet access } \\
\mathbf{2 0 1 5}\end{array}$ \\
\hline Supported municipalities in III.2.1.2 (n=98) & 12.94 & 8.46 & 7.75 & 5.32 \\
\hline \% change from baseline (2010=100\%) & $100.0 \%$ & $65.4 \%$ & $59.9 \%$ & $41.1 \%$ \\
\hline \hline Unsupported municipalities in III.2.1.2 (n=331) & 15.81 & 10.36 & 9.54 & 7.89 \\
\hline \% change from baseline (2010 = 100\%) & $100.00 \%$ & $65.6 \%$ & $60.4 \%$ & $49.9 \%$ \\
\hline \hline
\end{tabular}

Table 2 shows that in all supported years 2010, 2013, 2014 and 2015, there was a lower number of persons per Internet access compared to the situation in unsupported municipalities. Overall, the data reflect the gradual introduction of the Internet throughout the Czech Republic, however, in the supported municipalities the number of persons without access to the Internet decreased faster compared to the situation in 2010. The dynamics of the introduction of the Internet in supported municipalities as of 31 December 2015 was $8.8 \%$ higher in supported municipalities compared to the non-supported municipalities. In the supported municipalities, there were on average 5.32 inhabitants per Internet connection, in the unsupported municipalities the value of 7.89 inhabitants per Internet connection was according to the data as of 31 December 2015. The supported municipalities also achieved better values in terms of quality and speed of connection at all available speed intervals, i.e., up to $30 \mathrm{Mbit} / \mathrm{s}$, from 30 to $100 \mathrm{Mbit} / \mathrm{s}$ and also in the interval of $100 \mathrm{Mbit} / \mathrm{s}$ and more (see Table 3).

Tab 3. Status in 2015 - Internet connection quality in supported municipalities - Number of supported / planned residents from RDP per one available connection in the speed range up to 30/100 Mbit/s, and $100 \mathrm{Mbit} / \mathrm{s}$ and more in 2015. Source: own processing and data calculations according to data of the Ministry of Agriculture (2016) and Czech Telecommunication Office (2016)

\begin{tabular}{|c|c|c|c|}
\hline & $\begin{array}{c}\text { Speed range up to } 30 \\
\text { Mbit / s } 2015\end{array}$ & $\begin{array}{c}\text { Speed interval from } 30 \\
\text { Mbit / s (inclusive) to } 100 \\
\text { Mbit / s } 2015\end{array}$ & $\begin{array}{c}\text { Available connection in } \\
\text { the } 100 \text { Mbit / s rate and } \\
\text { more } 2015\end{array}$ \\
\hline $\begin{array}{r}\text { Supported municipalities in III.2.1.2 } \\
(\mathrm{n}=98)\end{array}$ & 3.38 & 20.12 & 93.88 \\
\hline $\begin{array}{r}\text { Unsupported municipalities in } \\
\text { III.2.1.2 }(n=331)\end{array}$ & 4.34 & 29.13 & 122.07 \\
\hline
\end{tabular}

\subsection{Socio-economic performance in supported and unsupported municipalities}

The socio-economic performance in rural areas was also assessed from two points of view. Firstly, it was a comparative analysis of socio-economic development in supported and unsupported municipalities. Secondly, the analysis also focuses on the evaluation of alternative attribution, i.e., the degree of importance of the subsidies provided compared to other subsidies.

Tables 4 and 5 show the results of selected socio-economic indicators divided into supported and unsupported municipalities. Of the total comparison, the supported municipalities clearly achieved better socio-economic development values in the case of a change in the total population, i.e., $+5.9 \%$ when compared to 2015 and 2009. On the contrary, unsupported municipalities achieved a growth of $+4.7 \%$. This difference was due to higher attractiveness of supported municipalities, which was reflected in higher values of migration balance $(+1.2 \%)$ compared to non-supported municipalities $(+1 \%)$. Supported municipalities also reached an increase of $1.2 \%$ in the number of economically active population as of 31 December 2015, while in non-supported municipalities this number increased only by $0.4 \%$. In other socioeconomic indicators, the values of supported and unsupported municipalities were almost identical without significant differences. 
Tab 4. Comparison of selected indicators of supported beneficiaries from measure III.2.1.2 by size categories of municipalities. Source: own processing and calculations according to data of the Ministry of Agriculture (2016) and CSO (2016)

\begin{tabular}{|c|c|c|c|c|c|c|c|c|}
\hline \multirow[b]{2}{*}{$\begin{array}{c}\text { Municipality size category } \\
\text { (in brackets the number of RECIPIENT } \\
\text { projects included in the analysis) }\end{array}$} & \multicolumn{8}{|c|}{ Municipalities with subsidies of the measure III.2.1.2 - BENEFICIARIES } \\
\hline & 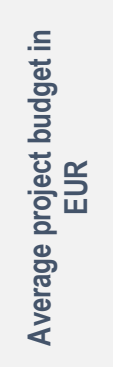 & 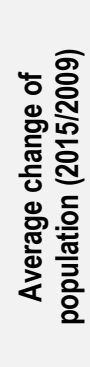 & 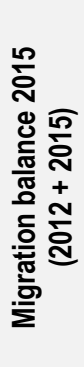 & 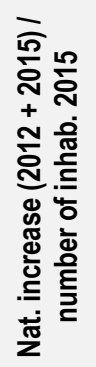 & 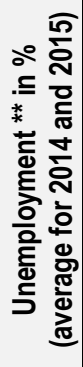 & 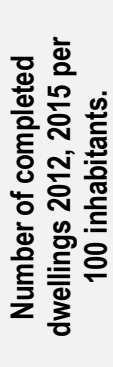 & 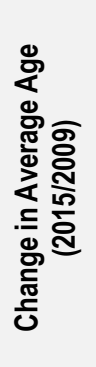 &  \\
\hline up to 100 inhabitants $(n=11)$ & 118,181 & 1.089 & 0.018 & -0.005 & 6.9 & 0.413 & 0.997 & 1.018 \\
\hline $101-200$ inhabitants. $(n=54)$ & 191,209 & 1.049 & 0.016 & -0.004 & 6.9 & 0.635 & 1.014 & 1.017 \\
\hline $201-300$ inhabitants. $(n=63)$ & 171,819 & 1.049 & 0.000 & -0.003 & 6.7 & 0.704 & 1.025 & 0.994 \\
\hline $301-500$ inhabitants. $(n=108)$ & 197,853 & 1.041 & 0.011 & -0.001 & 7.2 & 0.548 & 1.037 & 0.994 \\
\hline 501 and more inhabitants $(n=23)$ * & 162,763 & 1.180 & 0.041 & 0.004 & 5.8 & 1.359 & 1.016 & 1.132 \\
\hline TOTAL, beneficiaries for III.2.1.2 $(n=259)$ & 183,635 & 1.059 & 0.012 & -0.002 & 6.9 & 0.670 & 1.026 & 1.012 \\
\hline
\end{tabular}

* Note: The breakdown of municipalities by size category refers to data by population for 2015, not 2007.

Tab 5. Comparison of selected indicators of unsupported applicants from measure III.2.1.2 by size categories of municipalities. Source: own processing and calculations according to data of the Ministry of Agriculture (2016) and CSO (2016)

\begin{tabular}{|c|c|c|c|c|c|c|c|c|}
\hline \multirow[b]{2}{*}{$\begin{array}{l}\text { Municipality size category } \\
\text { (the number of projects from } \\
\text { unsuccessful applicants included in the } \\
\text { analysis is shown in brackets) }\end{array}$} & \multicolumn{8}{|c|}{$\begin{array}{l}\text { Municipalities without subsidies of the measure III.2.1.2 - UNSUCCESSFUL } \\
\text { APPLICANTS }\end{array}$} \\
\hline & 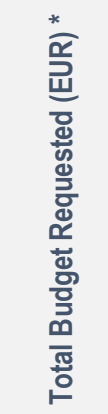 & 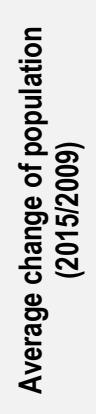 & 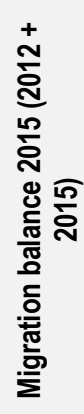 & 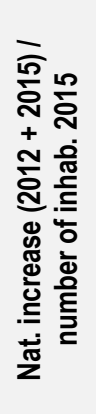 &  & 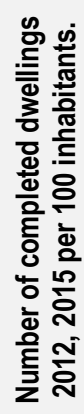 & 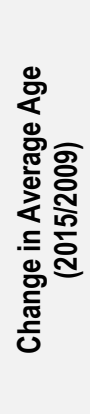 & 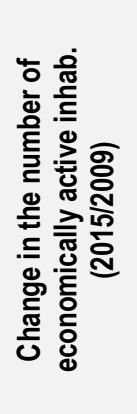 \\
\hline up to 100 inhabitants $(n=59)$ & 96,394 & 1.081 & 1.014 & -0.008 & 6.0 & 0.377 & 1.017 & 1.048 \\
\hline $101-200$ inhabitants. $(n=267)$ & 128,031 & 1.038 & 0.008 & -0.005 & 7.3 & 0.652 & 1.021 & 1.007 \\
\hline $201-300$ inhabitants. $(n=365)$ & 118,203 & 1.046 & 0.011 & -0.001 & 6.7 & 0.795 & 1.026 & 1.000 \\
\hline $301-500$ inhabitants. $(n=720)$ & 160,652 & 1.032 & 0.006 & -0.001 & 6.9 & 0.587 & 1.032 & 0.985 \\
\hline 501 and more inhabitants $(n=87)$ & 207,087 & 1.182 & 0.035 & 0.005 & 5.6 & 1.195 & 1.012 & 1.142 \\
\hline $\begin{array}{l}\text { Total unsuccessful applicants III.2.1.1 } \\
\text { ( } \mathrm{n}=1498)\end{array}$ & 144,661 & 1.047 & 0.010 & -0.002 & 6.8 & 0.676 & 1.027 & 1.004 \\
\hline
\end{tabular}

* Note: Required 'Co-financing Expenditure' as the sum of the EU contribution and the contribution from the national sources indicated in the application, translated at the 27 CZK / EUR rate (2016).

** Note: According to the CZSO, this is a new indicator called the share of unemployed persons (recorded only since 2014) and is not comparable with the previous "unemployment rate". 'Share of unemployed persons' (\%) expresses the share of the register. attainable job seekers aged 15-64 of all residents aged 15-64.

Alternative attribution, i.e., the effect achieved by another activity or intervention, was evaluated both by questionnaire and telephone surveys, and, also, by the Central Register of Subsidies (CERS) data. The questionnaire and telephone surveys showed that investments in supported municipalities were of crucial importance and scope. These municipalities confirmed in the survey that they would be able to realize the investments only to a limited extent, gradually over the coming years, while having to limit their spending on other development activities of the municipality (see also the deadweight assessment above). This finding also confirmed the analysis of official CERS statistics, whose data was assigned by the author to a representative sample of beneficiaries who participated in the questionnaire survey $(n=67)$. 
The provided RDP grants of the given measure accounted for $41 \%$ of the volume of all grants registered in this database. Other subsidies from national sources accounted for $42 \%$ and the support of Operational Program Environment achieved the level of $16 \%$. It is quite evident that the rate of alternative attribution is low and the financial support under the Rural Development Policy was of crucial importance for these rural municipalities.

\section{Conclusion}

The SMART village concept is very complex and answers a number of questions related to the current trends in the development of the digital economy on the one hand, and on the other hand, the possibilities for solving problems that are typical of rural areas. In this context, pressure can be expected on new forms of cooperation of local actors, creative solutions to local problems and challenges of development (including climate change, lowcarbon economy, etc.), finding suitable ways to effectively ensure the functioning of rural communities within urban-rural relations and also looking for ways to ensure the efficient provision of public services in the territory. For this reason, the paper evaluated experience with the support of two sub-themes of the SMART village concept, i.e., improvement of infrastructure conditions for provision of services in rural municipalities and increasing the availability of ICT infrastructure as a basis for the digital economy. These aspects were assessed on the example of the relevant EU rural development policy tool applied in the Czech Republic in the 2007-2013 programming period. The paper focused on the evaluation of the impact of this support with a certain time lag from the end of the project implementation period (i.e., in 2016 and the final acceptance of the evaluation results by the European Commission).

It is evident from the performed analyses that the implemented support was well targeted in rural municipalities. The newly built or reconstructed infrastructure of civic amenities and services provides facilities not only for the citizens of the supported municipalities, but there is also a significant impact on the residents of other catchment or neighbouring municipalities who also use this infrastructure. From a financial point of view, rural municipalities would find it very difficult to invest without subsidies in the relevant infrastructure. In this case, the endogenous development conditions of rural communities would be reduced. Supported infrastructure accelerated the dynamics of socio-economic development and increased the attractiveness of rural life. This fact illustrates the results of a comparative analysis in municipalities that did not receive the subsidy for the relevant infrastructure. In these municipalities, the level of socioeconomic development was perceived much worse compared to the situation in supported municipalities. These conclusions further confirmed the results of statistical data evaluation in selected socio-economic indicators. The supported municipalities clearly achieved better values of socio-economic development in case of a change in the total population and also in the migration balance. Supported municipalities also achieved higher growth in the number of economically active inhabitants compared to the situation for unsupported municipalities. In other socio-economic indicators, the values for supported and non-supported municipalities were almost identical without any significant differences. The analysis concerning the alternative attribution showed that investments in supported municipalities represented a fundamental financial contribution to the development of the municipality.

The question of promoting ICT infrastructure and improving access to the Internet for the population is embarrassing. On the one hand, municipalities did not have a clear preference and priority to develop this infrastructure. That is why they included in the achieved values of the respective indicator all the inhabitants of the municipality who could use the Internet connection (e.g., projects for renovation of municipal office building, local library, cultural centre). The purpose of these projects was primarily aimed at restoring municipal-owned buildings, and access to the Internet was of secondary importance. However, the data of the Czech Telecommunication Office, which records the real dynamics of Internet implementation in the territory, are interesting in this respect. In the case of supported persons, in the period 2010 to 2015, this dynamics was higher among supported municipalities compared to non-supported municipalities, including better values in terms of quality and speed of connection. It is clear that the investments made in the infrastructure of civic amenities have 
significantly contributed to making the supported municipalities more attractive and improving the conditions for ordinary civic activities.

The example of supporting the basic infrastructure for building the SMART village concept in the Czech Republic shows that the positive effects of the EU rural development policy tool were confirmed. It is mainly about improving the quality of life of the inhabitants and also creating better conditions for involvement of supported municipalities in activities that are covered by the SMART village concept. These results confirm the hypothesis of this paper stated in the introduction, i.e., that clearly targeted financial support for rural areas in the Czech Republic has helped to create conditions for the development of SMART villages, which were generally defined in the literature review (see European Commission, 2016; Nieto, 2019). However, the Cabalero's paradox of rural development policy is a crucial long-term problem, which indicates a negligible overall effect of this policy with regard to limited financial sources. In other words, the objectives of this policy are still very ambitious and the possibilities for achieving them are limited. Moreover, in the 2014-2020 programming period, these instruments have not continued and have become an integral part of EU cohesion policy. Even in the new programming period of 2021-2027 (Pělucha, 2018), it is not really planned to renew the structural tools of the EU rural development policy. On the contrary, this policy will continue to emphasize support for the agricultural concept of rural development. Notwithstanding, SMART village is not synonymous with SMART agriculture or "agriculture 4.0". For this reason, the main challenge for further research in this area is, in particular, the need to identify the necessary data to properly measure and assess the development of SMART villages in relation to standard socio-economic indicators. The availability of data on the geographical coverage of the territory by high-speed Internet at the municipal level (LAU II) is another necessary input for this type of analysis. Unfortunately, these data are not commonly available at the local level, either in time series or to varying degrees of Internet connection quality. This problem can be solved by increasing data sharing in public administration. At the same time, it is clear that digitization will fundamentally influence the potential and limits of the development of rural localities in the coming years.

\section{Acknowledgements}

This work was funded by the Czech Science Foundation (GACR) under Grant 17-12372S with a title "Theoretical and Methodological Perspectives of the EU's Neoproductivist Rural Development Policy", and by the Ministry of Agriculture of the Czech Republic, Rural development programme 2014-2020 (Technical Assistance - "Ex-post evaluation of the Czech Rural Development Programme 2007-2013").

\section{Academic references}

[1] Amcoff, J. (2012). Do rural districts die when their schools close? Evidence from Sweden around 2000. Educational Planning 20(3), 47-60.

[2] Bailey, N. \& Pill, M. (2015). Can the state empower communities through localism? An evaluation of recent approaches to neighbourhood governance in England. Environment and Planning C: Government and Policy 33(2), 289-304. DOI: $10.1068 / \mathrm{c} 12331 \mathrm{r}$.

[3] Barakat, B. (2015). A 'recipe for depopulation'? School closures and local population decline in Saxony. Population, Space and Place, 21(8), 735-753. DOI: 10.1002/psp.1853.

[4] Barca, F., McCann, P. \& Rodríguez-Pose, A. (2012). The case for regional development intervention: place-based versus place-neutral approaches. Journal of Regional Science. 52(1), 134-152. DOI: 10.1111/j.1467-9787.2011.00756.x.

[5] Bosworth, G. \& Venhorst, V. (2018). Economic linkages between urban and rural regions what's in it for the rural? Regional Studies 52(8), 1075-1085. DOI: 10.1080/00343404.2017.1339868. 
[6] Combes, P. P. \& Overman, H. G. (2004). The spatial distribution of economic activities in the European Union. In Henderson, J. V. \& Thisse, J. F., eds., Handbook of Regional and Urban Economics, Cities and Geography (pp. 2845-2909), Vol. 4. Amsterdam: Elsevier.

[7] Copus, A. K. \& de Lima, P. (2015). Territorial cohesion in rural Europe: the relational turn in rural development. London: Routledge.

[8] Corey, E. K. \& Wilson, M. (2006). Urban and Regional Technology Planning: Planning practice in the global knowledge economy. London: Routledge.

[9] Dustmann, C. \& Okatenko, A. (2014). Out-migration, wealth constraints, and the quality of local amenities. Journal of Development Economics 110, 52-63. DOI: 10.1016/j.jdeveco.2014.05.008.

[10] Eger, J. M. (2009). Smart Growth, Smart Cities, and the Crisis at the Pump A Worldwide Phenomenon. I-WAYS - The Journal of E-Government Policy and Regulation 32(1), 47-53. DOI: 10.3233/IWA-2009-0164.

[11] Elshof, H., Haartsen, T., Wissen, L. J. G. \& Mulder, C. H. (2017). The influence of village attractiveness on flows of movers in a declining rural region. Journal of Rural Studies 56, 39-52. DOI: 10.1016/j.jrurstud.2017.07.004.

[12] Etezadzadeh, Ch. (2016). Smart City - Future City? Smart City 2.0 as a Livable City and Future Market. Wiesbaden: Springer Fachmedien.

[13] Friedland, W. H. (1982). The end of rural society and the future of rural sociology. Rural Sociology 47, 589-608.

[14] Graham, M. (2011). Time machines and virtual portals: the spatialities of the digital divide. Progress in Development Studies 11(3), 211-227. DOI: 10.1177/146499341001100303.

[15] Halfacree, K. (2006). Rural space: constructing a three-fold architecture, In Cloke, P., Marsden, T. \& Mooney, P. Handbook of Rural Studies. Thousand Oaks: Sage.

[16] Haupt, M. (2018). The Evolutionary Journey to Society 4.0. Society 4. On-line article. Available at: https://medium.com/society4/evolution-of-societies-93a5f0f9b31.

[17] Haan, E., Meier, S., Haartsen, T. \& Strijker, D. (2017). Defining „Success“ of local citizens” initiatives in maintaining public services in rural areas: A professional's Perspective. Sociologia Ruralis 58(2), 312-330. DOI: 10.1111/soru.12173.

[18] Hite, J. (1997). The Thünen model and the new economic geography as a paradigm for rural development policy. Review of Agricultural Economics 19(2), 230-240. DOI: $10.2307 / 1349738$.

[19] Hoggart, K. (1990). Let's do away with rural. Journal of Rural Studies, 6(3), 245-257. DOI: 10.1016/0743-0167(90)90079-N.

[20] Kouřilová, J. (2018). Is a Basic School Important for a Local Development in Small Rural Villages? Case Study of the Stredocesky Region in the Czech Republic. In: Miczorek, W., ed., A World of Flows: Labour Mobility, Capital and Knowledge in an Age of Global Reversal and Regional Revival (pp. 104-105). Falmer Brighton: Regional Studies Association.

[21] Malecki, E. J. (2003). Digital development in rural areas: potentials and pitfalls. Journal of Rural Studies 19(2), 201-214. DOI: 10.1016/S0743-0167(02)00068-2.

[22] Mitchell, W. (2007). Intelligent cities. UOC Papers 5. 4-9.

[23] Naldi, L., Nilsson, P., Westlund, H. \& Wixe, S. (2015). What is smart rural development? Journal of Rural Studies, 40, 90-101. DOI: 10.1016/j.jrurstud.2015.06.006.

[24] Pant, L. P. \& Odame, H. H. (2017). Broadband for a sustainable digital future of rural communities: A reflexive interactive assessment. Journal of Rural Studies, 54, 435-450. DOI: 10.1016/j.jrurstud.2016.09.003.

[25] Pělucha, M. (2012). Venkov na prahu 21. století. Praha: Alfa nakladatelství. 
[26] Pelucha, M. \& Kveton, V. (2017). The role of EU rural development policy in the neoproductivist agricultural paradigm. Regional Studies 51(12), 1860-1870, DOI: $10.1080 / 00343404.2017 .1282608$.

[27] Pělucha, M. (2018). Reforma Společné zemědělské politiky EU [Background Document]. Praha: University of Economics.

[28] Philip, L. J., Cottrill, C. \& Farrington, J. (2015). "Two-speed" Scotland: patterns and implications of the digital divide in contemporary Scotland. Scottish Geographical Journal 131(3-4), 148-170. DOI: 10.1080/14702541.2015.1067327.

[29] Riddlesden, D. \& Singleton, A. D. (2014). Broadband speed equity: a new digital divide? Applied Geography 52, 25-33. DOI: 10.1016/j.apgeog.2014.04.008.

[30] Salemink, K., Strijker, D. \& Bosworth, G. (2017). Rural development in the digital age: A systematic literature review on unequal ICT availability, adoption, and use in rural areas. Journal of Rural Studies 54, 360-371. DOI: 10.1016/j.jrurstud.2015.09.001.

[31] Scott, M. (2013). Resilience: A conceptual lens for rural studies? Geography Compass 7(9), 597-610. DOI: 10.1111/gec3.12066.

[32] Townsend, L., Sathiaseelan, A., Fairhurst, G. \& Wallace, C. (2013). Enhanced broadband access as a solution to the social and economic problems of the rural digital divide. Local Economy: The Journal of the Local Economy Policy Unit 28(6), 580-595. DOI: $10.1177 / 0269094213496974$.

[33] Van Steen, P. J. M. \& Pellenbarg, P. H. (2010). Population change and spatial transformation in the Netherlands. Tijdschrift voor economische en sociale geografie. 101(5), 612-618. DOI: 10.1111/j.1467-9663.2010.00636.x.

[34] Vaznoniené, G. \& Pakeltiené, R. (2017). Methods for the assessment of rural social infrastructure needs. European Countryside, 9(3), 526-540. DOI: 10.1515/euco-20170031.

[35] Woods, M. (2006). Redefining the „rural question“: the new „politics of the rural“ and social policy. Social Policy \& Administration 40(6), 579-595. DOI: 10.1111/j.14679515.2006.00521.x.

[36] Woods, M. 2011. Rural. London: Routledge.

Other sources

[37] Caballero, M. J., Taminich, I., Hoberg, Y., de Dinechin, F. \& Mc.Mahon, M. (2005). Agriculture, Rural Development and Land Policies, [cit. 2019-02-20]. Available at: http://siteresources.worldbank.org/INTMEXICOINSPANISH/Resources/capitulo-8.pdf.

[38] CERS (2016). The Central Register of Subsidies. Official database of subsidies provided to Czech municipalities.

[39] CSO (2016). Selected socioeconomic indicators of municipalities in the Czech Republic. Czech Statistical Office.

[40] Czech Telecommunication Office (2016). Data on Internet access in selected municipalities. Data were used in the ex-post evaluation of the RDP CR 2007-2013 in 2016.

[41] ESPON (2017a). Shrinking rural regions in Europe - Towards smart and innovative approaches to regional development challenges in depopulating rural regions. ESPON, October 2017.

[42] ESPON (2017b). Territorial Cooperation for the future of Europe. ESPON, Luxembourg, May 2018. 
[43] ESPON (2017c). The territorial and urban dimensions of the digital transition of public services. ESPON, Luxembourg, October 2017.

[44] European Commission (2016). EU Action for SMART VILLAGES. Available on-line: https://ec.europa.eu/agriculture/sites/agriculture/files/rural-development-2014-2020/lookingahead/rur-dev-small-villages_en.pdf.

[45] European Commission (2017a). EU a Jednotný digitální trh. Directorate-General for Communication (European Commission), 2017. [online]. Available at: https://publications.europa.eu/en/publication-detail/-/publication/8084b7f3-6777-11e7-b2f201aa75ed71a1/language-cs.

[46] European Commission (2017b). Industry 4.0 in agriculture: Focus on loT aspects. Digital Transformation Monitor on-line available at https://ec.europa.eu/growth/toolsdatabases/dem/monitor/sites/default/files/DTM_Agriculture\%204.0\%20loT\%20v1.pdf [cit. 2018-12-05].

[47] Eurostat (2018). Eurostat regional yearbook - 2018 edition. European Union, Luxembourg, August 2018.

[48] Lund, S. \& Manyika, J. (2016). Digital globalization: the new era of global flows. McKinsey Global Institute, March 2016. Available at:

https://www.mckinsey.com/ /media/McKinsey/Business\%20Functions/McKinsey\%20Digital /Our\%20Insights/Digital\%20globalization\%20The\%20new\%20era\%20of\%20global\%20flow s/MGI-Digital-globalization-Full-report.ashx.

[49] Ministry of Agriculture of the Czech Republic (2012). Program rozvoje venkova České republiky na období 2007-2013 (Czech Rural Development Programme 2007-2013), Praha, September 2012, Ministerstvo zemědělství ČR.

[50] Ministry of Agriculture (2016). Data for the measure III.2.1.2 of the Czech Rural Development Programme 2007-2013. Data were used in the ex-post evaluation of the RDP CR 2007-2013 in 2016.

[51] Nieto, E. (2019). Smart Villages: A new concept for rural development. The Scitech Europa, 17th May 2019. On-line article available at: https://www.scitecheuropa.eu/smartvillages-rural-development/95112/.

[52] OECD (2006). The New Rural Paradigm - Policies and Governance. OECD Rural Policy Reviews, Organisation for Economic Cooperation and Development, ISBN 92-64-02390-9.

[53] OECD (2010). Strategies to Improve Rural Service Delivery. OECD Publishing, Paris. http://dx.doi.org/10.1787/9789264083967-en.

[54] OECD (2014). Innovation and Modernising the Rural Economy. OECD Rural Policy Reviews. Paris: OECD Publishing.

[55] OECD (2016). OECD Regions at a Glance 2016. OECD Publishing, Paris. ISBN 978-9264-25679-8. 